\title{
圧延加工された低炭素鋼の疲労過程中の転位組織*
}

\author{
上村 正 雄 ${ }^{*} 川$ 辺秀 昭*** 山田朝 治****
}

\section{Dislocation Structures during Fatigue Deformation of Rolled Low Carbon Steel}

by

\author{
Masao Uemura, Hideaki Kawabe and Tomoharu YamadA \\ (Faculty of Engineering, Osaka University, Suita)
}

It is known that fatigue induced dislocations structures in iron and low carbon steel are cell structure at high stress amplitude, and band structure at low stress amplitude.

The authors made fatigue testıng of low carbon steel specimens, which had been rolled beforehand to give cell structures, at low stress amplitude, and examined the dislocation structures of these specimens, comparing with those of the annealed specimen by the transmission electron microscope.

The results obtained are as follows :

(1) Two types of subboundaries have been recognized in the fatigue process of the rolled specimen at low stress amplitude. The one has larger misorientation between the neighboring subgrains, and the other has almost no misorientation. The former is characteristic of the rolled specimen, and can be imagined to be made well defined by the recovery during the fatigue deformation. The latter is similar to the subboundary recognized in the annealed specimen for the low amplitude fatigue.

(2) The cell size and dislocation density both in the annealed and rolled specimens become similar just before the fatigue fallure. These results are similar to those observed in high stress fatigue.

(3) The annihilation of dislocations occurs in the rolled specimens, perhaps by abnormally high vacancy concentration produced during the fatigue process.

(4) The consumption of vacancy by the climb motion of the edge dislocation, or the ann1hilation of edge dislocation, seems to delay the generation of pores on the surface in the rolled specimen, and thus the fatigue strength of the rolled specimen seems to increase.

(Received Sep. 24, 1970)

\begin{abstract}
1 緒言
* 原稿受理 昭和45年 9 月 24 日

** 学生会員 大阪大学大学院 吹田市字山田上

*** 大阪大学工学部 吹田市字山田上

**** 正会員 大阪大学工学部 吹田市字山田上
\end{abstract}

著者らは，前報において，低炭素鋼の焼なむ乙材， 圧延材の高応力に拈㲿る疲労過程中の転位組織変化を 観察し, 両者の疲労変形機構について考察を行なった。

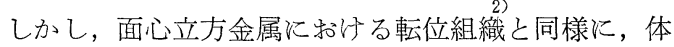
心立方金属である鉄拈よび低炭素鋼に打いても，疲労 寿命 $N_{f}=10^{5}$ 程度を境として, 高応力疲労と低応力 疲労に分汸られる。そして，それに応じて内部組織は， 高応力疲労に括いては cell 組織が形成され繰返し応 力が低下するとともに, cell 組織を構成する個々の副
結晶粒は大きくなってゆき, 低応力疲労に和いては, 転位は band 組織に配列している。しかしこの場合, 転位密度は高応力疲労と低応力疲学々であまり差がな く, $7 \times 10^{9} \mathrm{~cm}^{-2}$ 程度を示している.

このような, 内部組織の差が，低応力疲労に括恀る 著しい疲労寿命の伸びと関連しているものと考えられ， このよ5な点から, 転位密度が高く, かつ cell が存 在する压延材を，焼なをし材に执いて cell 組織が観 察されていない低応力にて疲労試験を行なうことは, 疲労破壊機構ならびに圧延材の疲学強度上昇機構を研 究する上で非常に興味深いものと考光られる。よって 本報に括いては, 圧延材, 焼なまし材の低応力疲労試 験を行ない, 両者の転位組織変化の差を明らかにする とともに, 压延材の疲労変形機構について考察した。 


\section{2 実 験 方 法}

本実験に用いた，供試材料拈上び実験方法は，前報 と同じである、すなわら, 厚さ $150 \mu$ の $0.05 \% \mathrm{C}$ 低 炭素鋼を $950^{\circ} \mathrm{C} \times 10 \mathrm{hr}$ 真空中完全燒なましを行ない， その後エメリー紙研摩により，100 ルと $125 \mu$ の厚さ にし，この時のひずみを取り除くため， $750^{\circ} \mathrm{C} \times 20 \mathrm{hr}$ のひずみ取り焼な蛋しを行ない, $100 \mu$ の当のはその まま燒なま乙材試料と乙, $125 \mu の b の は ， 100 \mu$ に圧 延加工を行ない, 圧延材試料とした。この時の平均結 晶粒径は， 350 ルで市った。これらの試験片を高張力 鋼にて作製した平面曲げ疲学試験片の, 平行部分の表 裏に, シアノボンドにて張り付け, シェンク型平面曲 げ瘦労試験機（1800 cycles/min）にて，瘦学試験を 行なった。

この時, 加壳た応力は $20 \mathrm{~kg} / \mathrm{mm}^{2}$ である.この応 力では，焼なをし材，压延村試験片はそれぞれ，1.5 $\times 10^{6} \mathrm{cycles}, 4 \times 10^{6} \mathrm{cycles}$ にて破断した。よって低応 力疲学と考光られる。このよらな試験片より, 前報に 示した方法で, 薄膜試料を作成し, 電子顕微鏡観察 (加速電压 $100 \mathrm{kV}$ ) を行なった。平均転位密度は, Ham の方法老用いて求めた。この際, 薄膜の厚さは すべて $1600 \AA$ 孝用いだ。

な特、コントラストの消えている転位に対する補正 や，薄膜作製時に生じると考兄られる転位の再配列等 については考慮していないので，実際の転位密度より いくぶん低めの值になっているるのと考えられる。

\section{3 実験結果および考察}

\section{$3 \cdot 1$ 焼なむし材の疲労変形挙動}

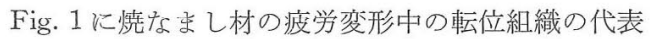

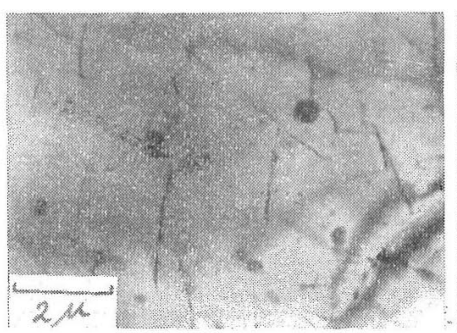

(a) $N=5 \times 10^{3}$

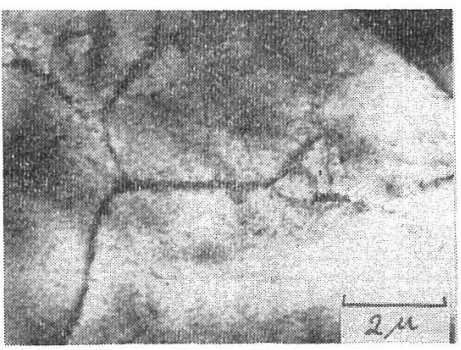

(c) $N=8 \times 10^{5}$

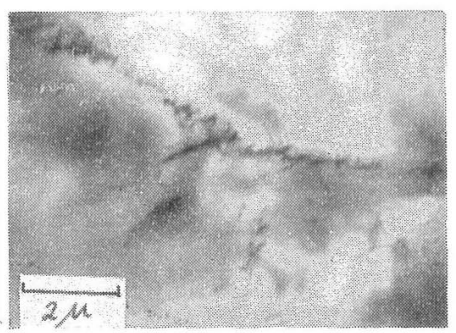

(b) $N=2 \times 10^{5}$

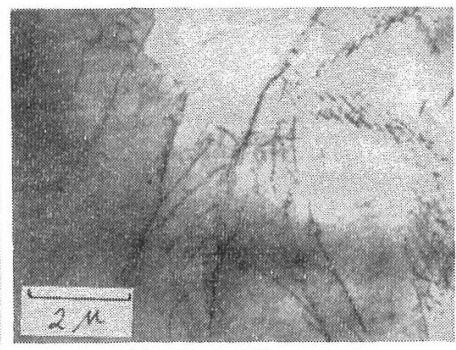

(d) $N=5 \times 10^{6}$
Fig. 1. Changes of dislocation arrangement of annealed specimens during fatigue deformation process at a stress of $20 \mathrm{~kg} / \mathrm{mm}^{2}$.
的なものを亦す. Fig. 1 (a)は応力繰返し数 $N=5 \times 10^{3}$ のもので, 転位は一様に分布して括り, 平均転位密度 も, 焼なまし状態の $10^{8} \mathrm{~cm}^{-2}$ 程度上り少し増加してお

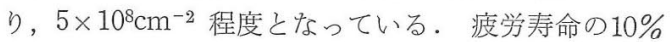
程度の, $N=2 \times 10^{5}$ では，転位は互いに tangle 乙始 め, 転位密度の高い場所と, それらの間の転位密度の 低い場所とに別れ始める。Fig. 1 (b)は，この段階にお ける比較的転位が密に tangle した副境界を示す。そ して疲労寿命の約 $50 \%$ 程度に拈いては，結晶粒内では， よだ副結晶粒組織は発達していないが，Fig. 1(c)のよ らに, 粒界近傍に拾いては, 副結晶粒が形成されてい る。こ狆は，4〜5 $\mu$ 程度である。破断時 $N=1.5 \times 10^{6}$ では, Fig. 1(d)のよ5に結晶内部に拈いては, 未発達 な, band 組織に近い cell 組織が形成されている。こ の時の副結晶粒の大きさは，3１0 $\mu$ 程度であり転位 密度は, $3 \times 10^{9} \mathrm{~cm}^{-2}$ 程度である。このよ5に低応力 に扣いては, 高応力より, 副結晶粒の大きさは増し転 位密度は減少している。

このような副絬晶粒界は, square cross grid や hexagonal network あるいは, tilt boundary より成 っている.乙かて, cell 内と cell boundaryとの間の 転位密度の差はあまりなく, 疲労初期に多られるよう な転位が一様に分布している場所や, tangle した所な ぞも多く観察された。

このように, 低応力に拈いては, 結晶内部に拈いて は, 明確な cell 組織は形成されず, Lukáš らの結果 と, 注同様なものとなっているが, 結晶粒界近傍に 执いては, 比䡆的発達した副結晶粒が観察された。こ れは粒界に打りる応力集中效果のためと考帛られ，粒

界近傍から裂が発生する表面観察 結果と一致する。

\section{$3 \cdot 2$ 圧延材の疲労変形挙動}

Fig. 2 に圧延状態の転位組織を示 す。このように，压延材においては 不明確な cell 組織を成して拈り, 副結晶粒内の転位密度は，1〜 $4 x$ $10^{10} \mathrm{~cm}^{-2}$ 程度となっている。このよ らなものに, $2 \times 10^{6}$ cycles の繰返し 応力を与えたるのをFig. 3 (a)，(b)， (c)に示す。このように転位組織は， (a)ほとんど压延状態のままの組織の 場所，(b)再配列途上亡思われる転位 が密ではあるが，一様に分布した場 所，枕よび，非常に局部的ではある が，焼なまし材とほぼ同じような疲 労組織を成した(c)0よ5な場所が観 察される.このように高応力疲労の 場合と添ぼ同じような経過をたどり 


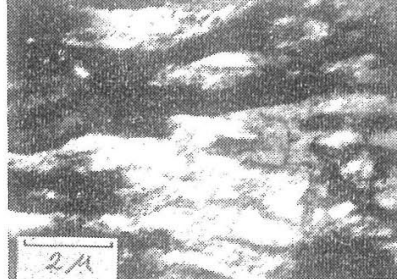

(a) Before rearrangement

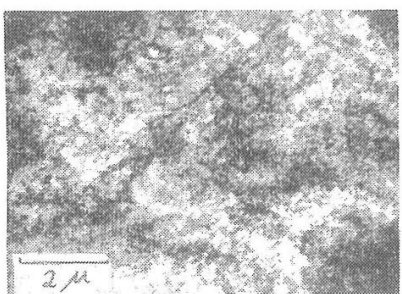

(b) During rearrangement

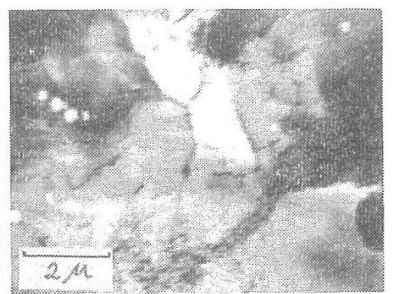

(c) After rearrangement

Fig. 3. Dislocation arrangement of rolled specimens after cycling; $N=2 \times 10^{6}$ at a stress of $20 \mathrm{~kg} / \mathrm{mm}^{2}$.

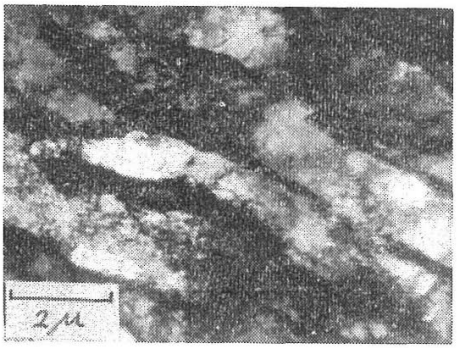

Fig. 2. Dislocation arrangement of rolled specimen.

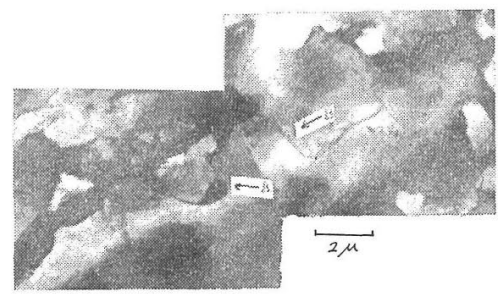

Fig. 4. Dislocation arrangement of rolled specimen after cycling; $N=4 \times 10^{6}$ at a stress of $20 \mathrm{~kg} / \mathrm{mm}^{2}$.

疲労変形が進行しているが，変形忏より局部的になっ ている。 そして破断寸前の $N=4 \times 10^{6}$ に和いては， Fig. 4 のよらに上く発達した cell組織が観察され，副 結晶粒の大きさる $2 \sim 8 \mu$, 転位密度も痩学変形が 充 分進んだと思われる場所の副結晶粒内では $5 \sim 8 \times 10^{9}$ $\mathrm{cm}^{-2}$ と焼なるし材とほぼ同じような状態になってい る。しかし，副結晶粒界は，焼な委し材とはかなり異 なったるのが観察される。すなわち，疲学変形後の圧 延材に扮訬る副結晶䊉は，Fig. 4 亿矢印Aで示された ような，隣接する副結晶粒間の方位差の非常に大きい ものと，矢印Bで示されたような，ほとえど方位差の 存在しないるのの二種類から形成されている. Aの上

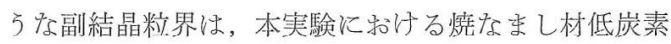
鋼の低応力疲労に特いては観察されなかったもので， 圧延材の低応力疲労特有の組織之考光られる。これは, 圧延加工によって形成された大きな方位差を有する副 結晶粒界が，疲労過程中の回復によって明確になった ものと思わ机る、Bは hexagonal network あるいは tilt boundary と思われる転位組織からなって扮り，
焼な尔し材に沶いて観察された副結晶粒界と似ている。 よってBは，疲労過程中に新たに形成されたものと思

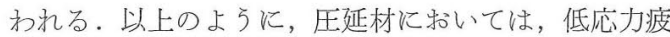
労飞䄧いて子明確な cell 組織が形成され副結晶粒の 大きさ，転位密度に関しては，焙なまし枌と㐫まり差 は認められなかったが，副結晶粒界にはかなりの差が 存在していた。

\section{$3 \cdot 3$ 原子空孔の拡散について}

压延材々焼なまし材の疲労変形前後の転位密度をま そめると TableI のようになる。こ机からも，压延 材飞括いては転位の消滅が起こっていることは明らか である。ところで，常温に执いて引張変形された鉄に 呿いては，ラセン転位と之みに多くの刃状転位が存在 乙 cell 組織足形成している。压延加工の場合にも Fig. 2 の5飞 cell 組織となって扮り刃状転位は多 く存在するものと考光られる。このような网状転位は， 点欠宿の吸収による上昇運動により消隇与るものと考 穴ら机る。

Table I. Average dislocation density of subgrain in heavily deformed regions in annealed and rolled specimens.

\begin{tabular}{c|c|c}
\hline & Annealed specimen & Rolled specimen \\
\hline$N=0$ & $10^{8}$ & $1 \sim 4 \times 10^{10}$ \\
Just before fracture & $3 \times 10^{9}$ & $5 \sim 8 \times 10^{9}$ \\
\hline
\end{tabular}

このような，低炭素鋼の常温に和ける疲労過程中の 点欠陌（主として空孔と考えられる）の拡散の可能性 汇関して, Derrick Jones らによる, 疲労変形中の桩

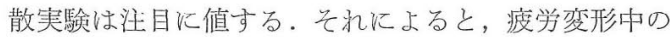
銅内の銀の拡散は，試料索疲労变形期間中に $300^{\circ} \mathrm{C}$ に 加熱したものと等しくなって招り，かれらはこの現象 は, 疲学变形中に形成された非常に高濃度の原子空孔 のためでと考光ている。同じく，冷間加工された銅

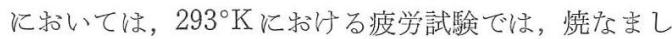

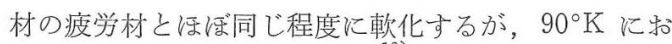
いては活とえど軟化していない. 拉上び疲学変形を受 汀た試料表面に pore が現われていることにより，本 実験に用いたような低炭素鋼においても，常温に打け 
る疲労変形中に, かなりの, 原子空孔の桩散が生じて いるもの之教觉られる。

$3 \cdot 4$ 焼なむし材括よび圧延材の疲学变形機構

以上の結果㸝よび表面観察結果より，焙なまし材，

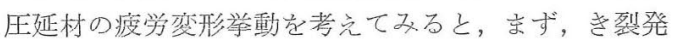
生機棈は，枧なまし材，厈延材之るにすへりの集中し た場所に形成された extrusion-intrusionによる応力 集中により，疲労過程の中期ごろ表面に現われてくる pore が連なり，微き裂になるのが一般的であるよう に思われる。これらの poreは, 焼なまし材では, 最 初はFig. 5 (a)のように一様に分布した形で現われ， 後期にはFig. 5 (b)のよ5に，副結晶粒を連想させるよ

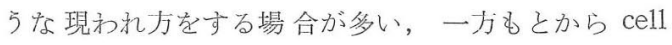
組織の存在する压延村に和いては, 最初から, 副絬晶

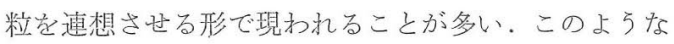
すべりの集中した場所の下部組織として，アルミニウ ム、銅などについて，副結晶粒組織あるいは ladder 組織, 打よび転位が密に，かつ一様に分布する組織が 観察されており低炭素鋼の場合にもこのような場所が 存在し，それぞれ，Fig. 5 (b)，(a)が，対応しているの ではないかと思われる。

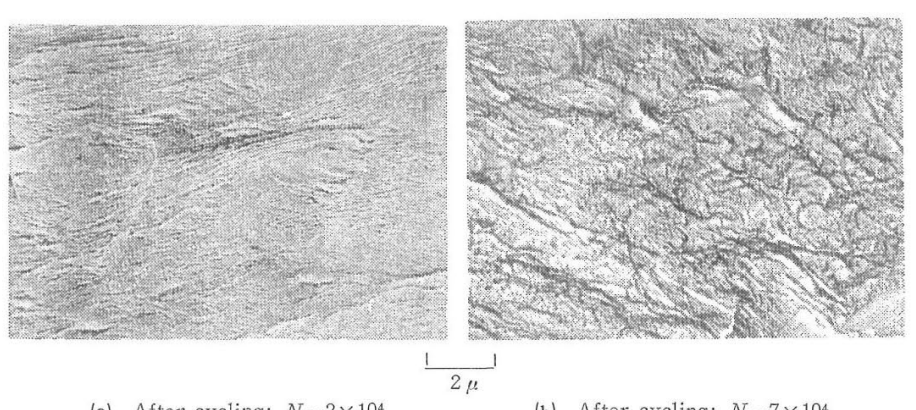

(a) After cycling; $N=2 \times 10^{4}$ (b) After cycling; $N=7 \times 10^{4}$

Fig. 5. Surface observation of annealed specimen during fatigue deformation process at a stress of $29 \mathrm{~kg} / \mathrm{mm}^{2}$.
返し応力に対して安定になるにつれ，(すなわら，転 位の上昇運動, それによる消隇を充分起こし, 転位密 度が焼なまし材と同程度になり，明確な cell 組織が 形成されるにつれ）表面に pore が現われだすと考え られる。そのため, 悓なまし材より pore の発生が幄

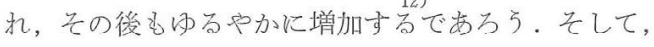
このことは，圧延材の疲労強度上昇の一因となるもの と考えられる。

\section{$3 \cdot 5$ Cell 組織について}

鉄のような，交差すべり㤂起こしやすく，副結晶粒 を形成しやすい材料については，隣接する副結晶粒間 の方位差の大きさより, 疲労破壊を統一的に説明しよ らとする試多もあるが, 本実験に特いては, 疲労強度 の高い在延村にの文，方位差の大さい副結晶粒界が存 在している。これより, 副結晶粒間の方位差の大小が, 疲労破壊の主因ではないよらに思われる。しかし，こ の点に関しては, 残留応力, 执よび疲労により新たに 形成された副結晶粒界亡, 㗔学変形中の回復作用によ って明確になった副結晶粒界との差などに関する, よ り詳細な研究が必要と思われる。

4 総括

$0.05 \%$ C 低炭素銅燒なむし材，打 よび压延材の疲学過程中の転位組織 観察の結果索之あると, 次のよう になる。

（1）焼なむし材に打いては，結晶 粒内は不明確な, cell 組織となって いたが，粒界近傍に拁いては，比較 的発達した副結晶粒組織が䚇察され た。

(2) 圧延材に必的副結晶粒界に は，焼なまし材と同様の方位差が小 さいものと，著しい方位差をもつも のとが観察された。
このような結果より，疲労過程中に形成された過剩 な原子空孔が，副結晶粒界を形成する転位や，一様に 分布する転位上を拡散していき, 結晶表面に現われて poreとなったものと考光られる。

よって，政なまし材では，応力の絽返しとともに， 転位密度扣上び原子宝孔密度の増加—原子筀孔が， 転位線上を，拡散していき，結晶表面に出てきてpore そなる—pore の增加によりき裂発生, というょう な経過家たどり瘦学変形が進行していくもの之考党ら れる。一方，压延材に扣いては，圧延加工により形成 された点欠陥扎よび疲労過程中に形成された空孔が， 压延材の幅広い cel1 境界を拡散していく場合，内部 の微視的, 巨視的残留応力を緩和するため, 刐状転位 が，空孔四収による上昇運動を起こし，内部組織が繰
（3）燒なるし材，压延材の，疲労破断寸前の組織は, 副結晶粒界の方位差では異なっていたが，副結晶粒の 大きさ, 転位密度は, 湾ぼ同じ程度となって必り, 高 応力痕労の場合より, 副結晶粒は大さくなり, 転位密 度は低くなっていた。

（4）圧延材に括いては, 痏学過程中に回復が起こり, 压延加工によって導入された。ラセン, 刃状転位の消 隇が起こっているのが锥察された。瘦学き裂発生に重

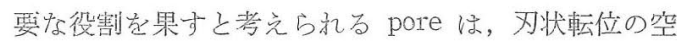
孔吸収により発生が遲れるもの之涍られ, これは, 压延材の疲労強度上昇の重要な因子と考えられる。

（5）副結晶粒間の方位差の大きさ之，疲学き裂発生 との間の関連性に関する結果は得られず,むしろ無関 係と思われた。 
終わりに,この研究を進めるにあたって, 有益なご 助言をいただいた, 大阪大学 高村正治助教授, およ び低炭素鋼を提供くださった住友金属中央研究所に, また本研究に協力していただいた小林茂樹君に厚く感 謝いたします。

（昭和 45 年 5 月 20 日 日本材料学会第 19 期通常総会学術講演会にて講 演）

\section{参 考 文 献}

1) 吉田 彰, 上村正雄, 川辺秀昭, 山田朝治, 材料, 18, 1106 (1969).

2) Feltner, C. E., and C. Larrd, Trans. AIME, 242, 1253 (1968).

3) Lukáš, P, M Klesnil, und P Ryš, Z. Metallkunde, 56, 109 (1965).

4) Lawrence, F. V., Jr. and R. C Jones, Metal. Trans., 1, 367 (1970).
5) Lukás, P., and M. Klesnil, Czech, J. Phys., 14, 600 (1964).

6) Ham, R. K., Phil. Mag, 6, 1183 (1961).

7) Vingsbo, O, Y Bergstrom, and G. Lagerberg, Ph11. Mag, 20, 1271 (1969).

8) Williams, H. D., and G C Smith, Phil Mag., 13, 835 (1966).

9) 吉田 彰, 川辺秀昭, 山田朝治, 材料, 19, 295 (1970).

10) Ikeda, S., J. Phys. Soc. Japan, 27, 1564 (1969).

11) Derrick Jones, W J , and W. D. Dover, Nature, 209, 704 (1966).

12) Broom, $T$, and $R K$ Ham, Proc. Roy. Soc, A 242, 166 (1957).

13) Forsyth, P. J E, Acta Met., 11, 703 (1963).

14) Laufer, E. E., and $W N$ Roberts, Phil. Mag, 10, 883 (1964).

15）小倉次夫, 辛島誠一, 金属学会誌, 34, 746 (1970). 